\title{
SURVIVORS AND SAVIOURS
}

\author{
The ultimate challenge.
}

\section{BY PHILIP T. STARKS}

$\mathrm{T}$ he airlocks close behind me, but I can't hear them. My ears register nothing but the radio and my breathing. White noise, the rhythmic acceptance and expulsion of recycled air, and my own inner dialogue keep me company as I take my first step. The ground compresses beneath my foot, but my protective gear mutes the full experience.

I was selected for this mission not because I'm the oldest or youngest, weakest or strongest, smartest or dimmest, but because I'm expendable. When you're a dead-end vehicle in an evolutionary war, your job is to die first. I've been awarded this step because I'm sterile.

Sterile not only describes me, but also the environment that I've survived in. I won't say, 'lived in', although the others seem hopeful enough to equate survival with living. I don't. Up until now, I've been surviving. However, with each step taking me farther from the enclave into the real world, I feel more alive.

And I'm not alone. Out here, the world is teeming with life. Some teams collaborate, some hold ground in extended battle and others triumph. The skeletal remains splintering beneath my feet, serving as coral-like scaffolding for microbial masters, remind me that when one team triumphs, another fails. I might be advancing, but my team is losing.

Many teams have lost, but I suppose the majority have survived. It's just my own bias that elevates birds over biofilm. But I find no comfort in these thoughts. So, while ploughing through this microbial minefield, I focus on stories of long extinct beasts: of mammals, birds, reptiles and insects. I recite parables explaining how the loss of honeybees was an ignored bioindicator of a New Age, and how financial and political interests handcuffed a timely response. I fill my mind with these details to shield me from my fears.

My mission is to find survivors, but the unspoken hope is to find females. That hope isn't buoyed by data or experience. Of almost 10,000 embryos, only 1,500 survived. Even this pathetic number stressed our pool of viable uteruses, forcing us to transfer as many as three to the younger soldiers. Most failed to implant, or perished shortly there-

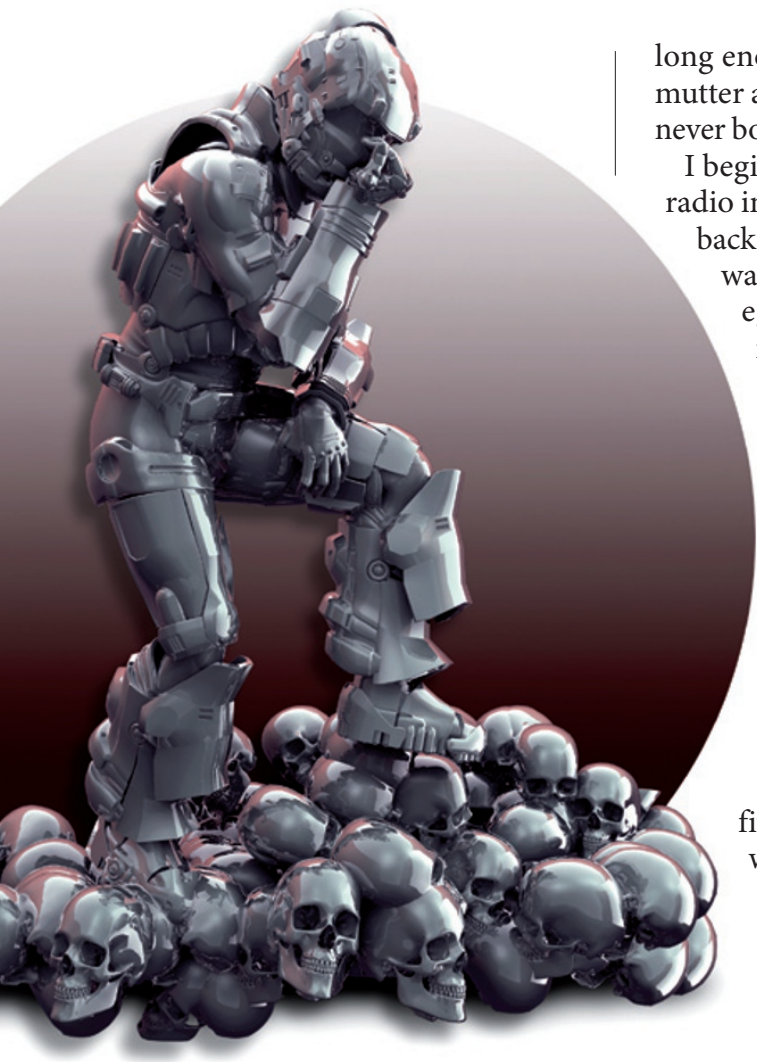

long enough to rejoin us. I mourn them, mutter a silent prayer, and wish they were never born.

I begin tallying the dead, then stop and radio in: "I count at least 150, I'm coming

back." I turn down the volume and don't wait for an answer. We fertilized the eggs, developed the embryos and reared the young. We took the survivors and released them, unprotected, into this world. We killed them: I just couldn't count every last dead child.

If I had, my count would have fallen short. My walk back to my sterile tomb was not solitary, and before I reached the airlock I felt a delicate hand tug my gloved finger.

"Don't leave me."

She is beautiful: eleven years old, fit, and without protective gear. Her words are stronger than she knows: with them, she has sealed both our fates. I am overcome with joy and grief: I am thrilled she breathes, but I wish I was dead.

"I won't leave you," I promised her. "Where are your friends?"

after. Our hopes were pinned on 350 fetuses, 280 of which survived birth; 165 enjoyed their ninth birthday, and prior to their tenth, we released them. Only 68 were female.

Now I'm searching for at least one. I understood that this trip would be long, and that the first steps would reveal our past failures. Despite these warnings, I didn't anticipate the boneyard I'd trample. The beauty of the growth encompassing them notwithstanding, these were my kin. Still, the horror of the eviscerated, cleanly consumed bodies was infinitely preferable to what I feared came next.

I pass through the final gateway, frightened but hopeful, but ultimately unprepared. My fears, developed and nourished in isolation, paled against this sight. Extinction nestles into one's arms more easily than a dead child. And I can't possibly hold all of the dead children.

Most of the food and water packets littering the ground are untouched. I am pleased, actually, by the advanced decomposition: $\rightarrow$ NATURE.COM

Follow Futures: @NatureFutures

$f$ go.nature.com/mtoodm most died immediately. Some of the bones, however, hold flesh. These children had survived, but not
"Gone," she said. I understood. She was the lone survivor of our challenge test. She has endured our abuse, and now I'll deliver her back to her abusers.

"So many people are looking forward to meeting you!" I confess to her the truth, but not its depth. I know that delivering her to the airlock will kill her freedom. She has survived, but only to be an egg donor. The goal of our research has always been to produce a generation that could thrive without protection. If she carries alleles that protect her against extinction-level pathogens, we need them.

I bring her to the airlock, call in the news and lie to her. "I'm going to step aside and protect the site, so I know you make it in." As she enters our crypt, I remove my mask, remember those we saved and mourn those we killed. As a dead-end vehicle, I am happy to reach my end. I breathe deeply, taste the Age of Microbes, and convince myself that the Age of Man is not over.

Philip T. Starks is an associate professor of biology at Tufts University. His research focuses mostly on the behaviour of social insects, but he has recently been exploring microbial communities. 